\title{
Presence of women in futsal. A systematic review
}

\author{
Alberto Sanmiguel-Rodríguez \\ Faculty of Language and Education. Nebrija University. Madrid. Spain. Faculty of Language and Education. University of Camilo José Cela. Madrid. Spain.
}

doi: 10.18176 /archmeddeporte.00048

Recibido: 01/09/2020 Aceptado: 01/04/2021

Key words: Futsal. Female. Sport. Review.

\section{Summary}

Futsal is one of the sports that has been gaining in number of practitioners worldwide. Among the groups in which the practice has grown in recent decades, women stand out. Thus, the objective of this review is to offer a vision of the most recent scientific publications in relation to the presence of women in futsal. For this, a systematic review was carried out from 2015 to 2020, searching with the terms of the UNESCO Thesaurus: "futsal" and "woman" in the Scopus and Dialnet databases, allowing the selection of original articles (experimental, descriptive, quasi -experimental and / or case studies) that included information on this line of research. A total of 381 articles were found, although after applying the inclusion criteria of the review they were reduced to 27 articles. These publications were divided into three main categories: 1) Research related to conditioning factors of training and competition in women, 2) Research related to injuries and other psychological variables in women and 3) Other topics investigated; doing a discussion about each of these categories. In conclusion, this systematic review makes it possible to quickly and easily observe the analysis of women's futsal research within the international context in recent years, as well as to identify the most relevant scientific issues today. Thus, there is a scarce number of publications on the presence of women in futsal in all the topics of study, and therefore, it is necessary to cover with greater scientific contribution given the great boom, extension and popularity that has been acquiring the figure of the woman in this sport.

\section{Presencia de la mujer en el fútbol sala. Una revisión sistemática}

\section{Resumen}

El fútbol sala es uno de los deportes que ha ido ganando en número de practicantes a nivel mundial. Entre los grupos en los que ha crecido la práctica en las últimas décadas, se destacan las mujeres. El objetivo de esta revisión es ofrecer una visión de las publicaciones científicas más recientes en relación a la presencia de la mujer dentro del futsal. Para ello se realizó una revisión sistemática desde 2015 hasta 2020, buscando con los términos del Tesaurus de la UNESCO: "futsal", "mujer" en las bases de datos Scopus y Dialnet, permitiendo seleccionar los artículos originales (estudios experimentales, descriptivos, cuasi-experimentales y/o estudios de caso), que incluían información sobre esta línea de investigación. Se encontraron un total de 381 artículos, aunque tras la aplicación de los criterios de inclusión de la revisión quedaron reducidos a 27 artículos. Estas publicaciones se distribuyeron en tres grandes categorías: 1) Investigaciones relacionadas con condicionantes del entrenamiento y la competición en la mujer, 2) Investigaciones relacionadas con lesiones y otras variables psicológicas en la mujer y 3) Otras temáticas investigadas; haciendo una discusión sobre cada una de estas categorías. Como conclusión, esta revisión sistemática permite observar de forma sencilla y rápida el análisis de las investigaciones de la mujer en el futsal dentro del contexto internacional en los últimos años, así como identificar los temas científicos más relevantes en la actualidad. Así pues, se halla un escaso número de publicaciones sobre la presencia de la mujer en el futsal en todas las temáticas de estudio,

Palabras clave:

Fútbol sala. Mujer. Deporte. Revisión. y por ello, resulta necesario cubrir con mayor aportación científica dado el gran auge, extensión y popularidad que ha ido adquiriendo la figura de la mujer en este deporte. 


\section{Introduction}

Futsal is one of the sports that has been gaining in number of practitioners worldwide. Among the groups in which the practice has grown in recent decades, women stand out'. Futsal, like soccer, has always been recognized as a sport played by men. This culture, for a long time, prevented girls from practicing this modality but, currently, there is a growing expansion of women's futsal with the creation of federated championships, leagues, national teams and clubs ${ }^{2,3}$. Futsal is a sport with a growing popularity, as well as its level of performance, both in men and women ${ }^{4}$.

Women's futsal and soccer are modalities that had their practice made official recently, only at the end of the $20^{\text {th }}$ century and, because they are not valued practices, they have few studies presented in the literature ${ }^{5,6}$. Investigating the development of elite women's sports careers can be a way to better understand how gender issues and the specific conditions of women's sports practice have influenced the lives and personal experiences of athletes ${ }^{7}$. Women face many barriers, discrimination, and stereotypes to participate in a worldwide sport. The findings of these authors ${ }^{8}$ indicated several variations of the social construction of female futsal players through a process of objectification, dialectics externalization, and internalization on futsal. On the other hand, despite this growing expansion of women's futsal, few studies have investigated the specific physiological demands of women within this sport ${ }^{9}$.

Likewise, the area of evaluation of the functional state of the neuromuscular system and its impact on the physical fitness characteristics of futsal women players is not sufficiently substantiated ${ }^{10}$. However, the inclusion of women in futsal in recent years has become a topic of interest for the academic community ${ }^{11}$. The presence of women in the sports field of futsal shows the change in mentality that there are sports for men and others for women; maybe that's the paradigm shift. In fact, women are increasingly involved with bodily practices, previously restricted to the male gender ${ }^{12}$. However, the incentive to practice women's futsal at Brazilian universities is still timid, despite being a very popular sport practiced in Brazil ${ }^{13}$.

The purpose of this study has been to carry out a review of the scientific literature from 2015 to 2020 that addresses the field of futsal, selecting only articles related to the presence of women for content analysis. Therefore, the objective of this study is to determine the amount of scientific papers that are published related to women in futsal, to analyse which are the most investigated topics in this field and thus establish which aspects are a little-studied field of research and therefore they offer more possibilities.

\section{Material and method}

The bibliographic review is a type of scientific article that, without being original, collects the most relevant information on a specific topic. Thus, for this review, a bibliographic search was carried out in the two most relevant international databases in this line of study. The first one, the Scopus database (Elsevier), was selected as it was a review in Social Sciences (texts in different languages). In addition, the Spanish Dialnet database was used as a complement. As keywords, the following terms were chosen from the UNESCO Theaurus (futsal, women and/or female). The inclusion criteria used in the review were the following:

- Articles published from January 1, 2015 to August 15, 2020.

- Articles that address any type of research related to futsal in the international context, incorporating experimental, descriptive, quasi-experimental studies and / or case studies.

- Articles that are published in English, Portuguese or Spanish.

- That the study analyse any variable related to women and futsal.

A total of 381 articles were found, but after applying the indicated selection criteria, the search brought together a total of 27 documents for analysis. Likewise, the work schedule for the search for information had four different phases, as can be seen below and in the flow diagram represented graphically in Figure 1.

Figure 1. Flow diagram of the systematic search process.

Flow chart of the review of publications on the presence of womwn in futsal. Years 2015-2020

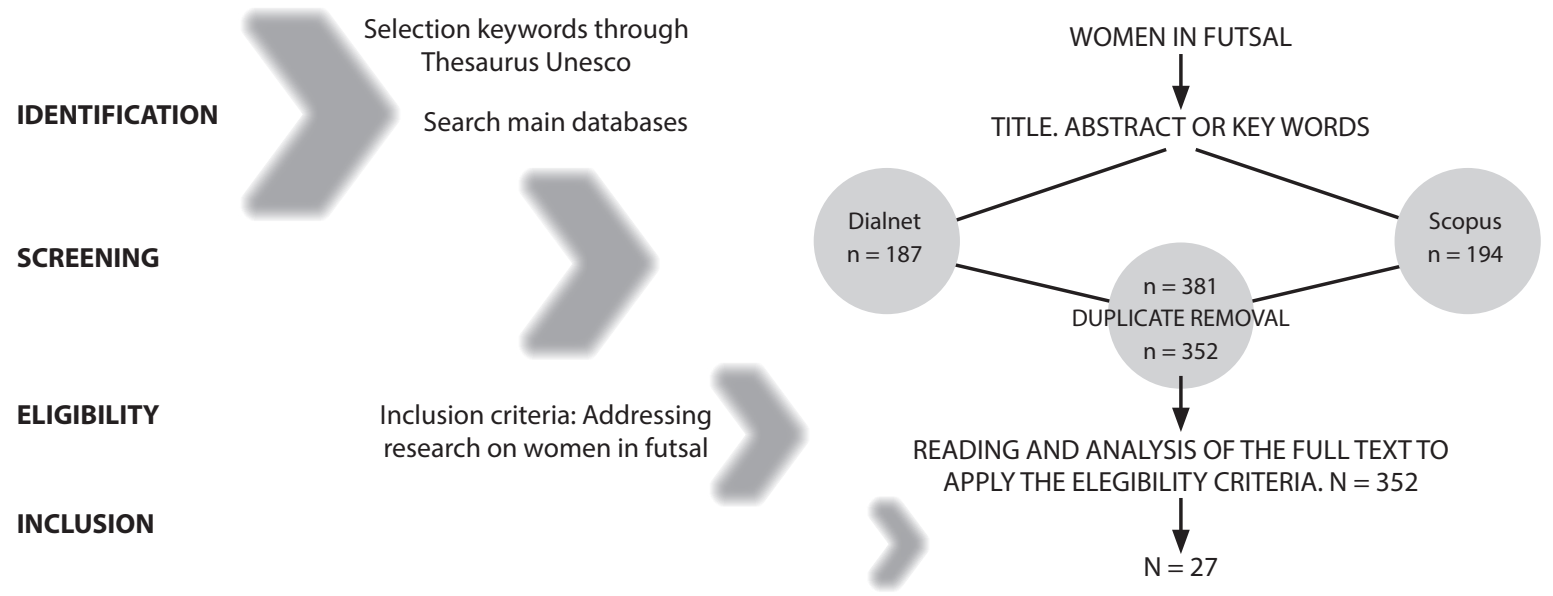


- $1^{\text {st }}$ Phase: Search and selection of descriptors through the UNESCO Thesaurus.

- $2^{\text {nd }}$ Phase: Detailed search in the scientific databases Scopus and Dialnet, using the inclusion criteria described above.

- $3^{\text {rd }}$ Phase: Analysis of the content of the articles and classification by subject.

- $4^{\text {th }}$ Phase: Categorization of articles and preparation of the manuscript: systematic review.

Once the 27 definitive articles had been selected, a detailed reading of all the articles was performed individually and a first categorization was made. The second phase was the analysis of the different articles and the specification of the three definitive categories. As a result of this deductive procedure, triangulating the information, the final classification of the articles was carried out in the three mentioned categories.

\section{Results}

Once the flow chart of the systematic review of publications on the presence of women in futsal had been made, the result was 27 publications. All of them were included in a categorization process by subject, finally finding three categories of analysis of the scientific literature (Table 1).

Table 1. Synthesis of the studies found on presence of women in futsal.

\begin{tabular}{|c|c|c|c|c|c|}
\hline Journal & Article title & Authors & Year & The purpose of the study & Results and conclusions \\
\hline \multicolumn{6}{|c|}{ Research related to conditioning factors of training and competition in women } \\
\hline Biol Sport & $\begin{array}{l}\text { Aerobic fitness and } \\
\text { performance in elite } \\
\text { female futsal players }\end{array}$ & $\begin{array}{l}\text { Barbero-Alvarez } \\
\text { et al. }\end{array}$ & 2015 & $\begin{array}{l}\text { The aim of this study was to } \\
\text { determine aerobic fitness in } \\
\text { elite female futsal players using } \\
\text { laboratory and field testing. }\end{array}$ & $\begin{array}{l}\text { Peak heart rare and post-exercise } \\
\text { blood lactate concentrations were not } \\
\text { significantly different between tests. Elite } \\
\text { female futsal players possess moderate } \\
\text { aerobic fitness. }\end{array}$ \\
\hline $\begin{array}{l}\text { JExerc Physiol } \\
\text { Online }\end{array}$ & $\begin{array}{l}\text { Comparison of } \\
\text { psychophysiological } \\
\text { responses in game } \\
\text { simulation and different } \\
\text { training sessions in } \\
\text { female futsal athletes }\end{array}$ & Barth et al. & 2016 & $\begin{array}{l}\text { The purpose of this study was to } \\
\text { compare the different } \\
\text { modes to quantifying the training } \\
\text { load in small-sided game (SSG), } \\
\text { repeated sprint ability (RSA), and } \\
\text { simulated match (SM). }\end{array}$ & $\begin{array}{l}\text { The results demonstrate that sessions } \\
\text { with SM and SSG show similar } \\
\text { psychological and physiological } \\
\text { responses, but lower than observed in } \\
\text { RSA training sessions. }\end{array}$ \\
\hline Biol Sport & $\begin{array}{l}\text { Evaluation of the } \\
\text { external and internal } \\
\text { workload in female } \\
\text { futsal players }\end{array}$ & Beato et al. & 2017 & $\begin{array}{l}\text { The aim of this study was to } \\
\text { quantify locomotor and mechanical } \\
\text { activities performed during a non- } \\
\text { competitive female futsal match, } \\
\text { measuring the differences between } \\
\text { the first and second half. }\end{array}$ & $\begin{array}{l}\text { Female futsal players decreased the } \\
\text { workload in the second half compared to } \\
\text { the first one during this non-competitive } \\
\text { match. It was found that fatigue impairs } \\
\text { the performance in the second part of } \\
\text { the game. }\end{array}$ \\
\hline $\begin{array}{l}\text { Theory and Practice } \\
\text { of Physical Culture }\end{array}$ & $\begin{array}{l}\text { Innovative approach } \\
\text { in modeling of motor } \\
\text { training of women"s } \\
\text { futsal teams }\end{array}$ & $\begin{array}{l}\text { Chernysheva } \\
\text { et al. }\end{array}$ & 2015 & $\begin{array}{l}\text { The purpose of the present research } \\
\text { was to simulate motor training } \\
\text { of women"s futsal national team } \\
\text { on the basis of an assessment } \\
\text { of the functional state of the } \\
\text { neuromuscular system. }\end{array}$ & $\begin{array}{l}\text { Simulation of situations of competitive } \\
\text { activity in training conditions makes it } \\
\text { possible to improve the abilities of female } \\
\text { football players to quickly perceive and } \\
\text { adequately assess the current game } \\
\text { situation, to make a decision depending } \\
\text { on the situation with regard to individual } \\
\text { characteristics of the functional state of } \\
\text { the neuromuscular system and motor } \\
\text { fitness. }\end{array}$ \\
\hline SpringerPlus & $\begin{array}{l}\text { Profile of 1-month } \\
\text { training load in male } \\
\text { and female football and } \\
\text { futsal players }\end{array}$ & $\begin{array}{l}\text { Clemente \& } \\
\text { Nikolaidis }\end{array}$ & 2016 & $\begin{array}{l}\text { The aim of this study was to analyse } \\
\text { the variance of training load } \\
\text { between male and female football } \\
\text { and futsal players. }\end{array}$ & $\begin{array}{l}\text { In this study it was possible to verify that } \\
\text { female players spent more time in high } \\
\text { intensity zones and that futsal training } \\
\text { sessions are more intense than football } \\
\text { sessions. }\end{array}$ \\
\hline Human Movement & $\begin{array}{l}\text { Heart rate variations } \\
\text { between training days } \\
\text { and types of exercise in } \\
\text { men and women futsal } \\
\text { and soccer players }\end{array}$ & Clemente et al. & 2018 & $\begin{array}{l}\text { The aim of the study was to compa- } \\
\text { re the heart rate (HR) responses of } \\
\text { women and men soccer and futsal } \\
\text { players during a 4-week period of } \\
\text { training. }\end{array}$ & $\begin{array}{l}\text { The tactical tasks and match were the } \\
\text { activities that contributed to increases in } \\
\text { heart rare max. }\end{array}$ \\
\hline $\begin{array}{l}\text { RBFF-Revista } \\
\text { Brasileira de Futsal } \\
\text { e Futebol }\end{array}$ & $\begin{array}{l}\text { Effecto de la } \\
\text { periodización con } \\
\text { cargas selectivas sobre } \\
\text { la incidência de lesiones } \\
\text { en un equipo de futsal } \\
\text { femenino durante } \\
\text { temporada competitiva }\end{array}$ & $\begin{array}{l}\text { Ruppel da } \\
\text { Rocha \& Delia } \\
\text { Venera }\end{array}$ & 2015 & $\begin{array}{l}\text { This study evaluated the effect of } \\
\text { selective loads periodization on } \\
\text { incidence of injuries in professional } \\
\text { female Futsal players during } \\
\text { competitive season. }\end{array}$ & $\begin{array}{l}\text { Selective loads periodization is adequate } \\
\text { and attends the requirements of the } \\
\text { sport decreasing the incidence of } \\
\text { injuries during competitive season in } \\
\text { female Futsal players. }\end{array}$ \\
\hline
\end{tabular}




\begin{tabular}{|c|c|c|c|c|c|}
\hline Journal & Article title & Authors & Year & The purpose of the study & Results and conclusions \\
\hline $\begin{array}{l}\text { RBFF-Revista } \\
\text { Brasileira de Futsal } \\
\text { e Futebol }\end{array}$ & $\begin{array}{l}\text { Incidência local de } \\
\text { finalizações e Gols } \\
\text { efetivados em um } \\
\text { campeonato de Futsal } \\
\text { feminino }\end{array}$ & $\begin{array}{l}\text { Galvão de } \\
\text { Miranda et al. }\end{array}$ & 2019 & $\begin{array}{l}\text { The objective was to identify and } \\
\text { quantify the local incidence of finals } \\
\text { and goals scored in a women's futsal } \\
\text { championship through an analytical } \\
\text { performance system. }\end{array}$ & $\begin{array}{l}\text { The regions closest to the opponent's } \\
\text { goal had the highest number of finals } \\
\text { and goals, so the modification of the } \\
\text { defensive systems of those regions is } \\
\text { necessary to avoid possible negative } \\
\text { results for the teams. }\end{array}$ \\
\hline The Anthropologist & $\begin{array}{l}\text { Effects of plyometric } \\
\text { training on anaerobic } \\
\text { capacity and motor } \\
\text { skills in female futsal } \\
\text { players }\end{array}$ & $\begin{array}{l}\text { Karavelioglu } \\
\text { et al. }\end{array}$ & 2016 & $\begin{array}{l}\text { This study was conducted to define } \\
\text { the effects of an 8-week plyometric } \\
\text { training program on anaerobic } \\
\text { capacity. }\end{array}$ & $\begin{array}{l}\text { A statistically significant difference was } \\
\text { observed in the following factors among } \\
\text { the female futsal players of leg power, } \\
\text { absolute peak power, absolute mean } \\
\text { power, vertical jump and speed. }\end{array}$ \\
\hline $\begin{array}{l}\text { Journal of Physical } \\
\text { Education }\end{array}$ & $\begin{array}{l}\text { Physiological and neu- } \\
\text { romuscular responses } \\
\text { during the game in } \\
\text { female futsal players }\end{array}$ & Kassiano et al. & 2019 & $\begin{array}{l}\text { The present study tested whether the- } \\
\text { re are differences in physiological and } \\
\text { neuromuscular responses in futsal } \\
\text { athletes during a friendly game. }\end{array}$ & $\begin{array}{l}\text { There was a substantial increase in lacta- } \\
\text { te from the moment before the start of } \\
\text { the game to the end of the first. }\end{array}$ \\
\hline $\begin{array}{l}\text { The Journal } \\
\text { of Strength \& } \\
\text { Conditioning } \\
\text { Research }\end{array}$ & $\begin{array}{l}\text { Comparative effects of } \\
\text { two interval shuttle- } \\
\text { run training modes on } \\
\text { physiological and per- } \\
\text { formance adaptations } \\
\text { in female professional } \\
\text { futsal players. }\end{array}$ & Teixeira et al. & 2019 & $\begin{array}{l}\text { The purpose of this study was to } \\
\text { analyze the effects of } 2 \text { shuttle-run } \\
\text { interval training (SRIT) models with } \\
1 \text { and } 3 \text { directional changes per } \\
\text { running bout on the aerobic and } \\
\text { anaerobic performances of elite } \\
\text { female futsal players. }\end{array}$ & $\begin{array}{l}\text { In elite female futsal players, SRIT15×15 } \\
\text { is a promising strategy to enhance } \\
\text { performance-related physical fitness } \\
\text { attributes in a short-term period during } \\
\text { the preseason. }\end{array}$ \\
\hline $\begin{array}{l}\text { Sportis: Revista } \\
\text { Técnico-Científica } \\
\text { del Deporte Escolar, } \\
\text { Educación Física y } \\
\text { Psicomotricidad }\end{array}$ & $\begin{array}{l}\text { Análisis de la carga } \\
\text { interna en los entrena- } \\
\text { mientos de fútbol sala } \\
\text { femenino de } 1^{\text {a }} \text { división } \\
\text { nacional }\end{array}$ & $\begin{array}{l}\text { Pascual Verdú } \\
\text { et al. }\end{array}$ & 2016 & $\begin{array}{l}\text { The aim of this study is to analyze } \\
\text { the heart rate (HR) and the rating } \\
\text { perception of effort (RPE) in training } \\
\text { women futsal players from the first } \\
\text { division team of the Spanish league. }\end{array}$ & $\begin{array}{l}\text { Having significant differences in the } \\
\text { results of maximum heart rate between } \\
\text { technical-tactical sessions and modified } \\
\text { games and between the physiological } \\
\text { and technical-tactical sessions. The } \\
\text { results showed that the modified games } \\
\text { session obtains values of heart rate and } \\
\text { the rating perception of effort greater } \\
\text { than the technical-tactical and physiolo- } \\
\text { gical work sessions. }\end{array}$ \\
\hline \multicolumn{6}{|c|}{ Research related to injuries and other psychological variables in women } \\
\hline Malays Orthop J. & $\begin{array}{l}\text { Incidence of football } \\
\text { and futsal injuries } \\
\text { among youth in } \\
\text { Malaysian Games } 2018\end{array}$ & $\begin{array}{l}\text { Ahmad- } \\
\text { Shushami \& } \\
\text { Abdul-Karim }\end{array}$ & 2020 & $\begin{array}{l}\text { The purpose of the study } \\
\text { was to analyse the incidence, } \\
\text { circumstances, and characteristics } \\
\text { of football and futsal injuries during } \\
\text { the Malaysian Games of } 2018 .\end{array}$ & $\begin{array}{l}\text { A total of } 48 \text { injuries were reported from } \\
26 \text { football matches, equivalent to } 64.64 \\
\text { injuries per } 1000 \text { match hours. The rate } \\
\text { of injury in women futsal players was } \\
\text { higher compared to men. }\end{array}$ \\
\hline *Science \& Sports & $\begin{array}{l}\text { *Short term creatine } \\
\text { loading without weight } \\
\text { gain improves sprint, } \\
\text { agility and leg strength } \\
\text { performance in female } \\
\text { futsal players }\end{array}$ & *Atakan et al. & 2019 & $\begin{array}{l}\text { *The main aim of this study is to } \\
\text { identify the effects of short-term } \\
\text { creatine supplementation on leg } \\
\text { strength, velocity and agility in } \\
\text { young female futsal players. }\end{array}$ & $\begin{array}{l}\text { *Creatine supplementation significantly } \\
\text { improved } 10 \mathrm{~m}, 20 \mathrm{~m} \text { and } 30 \mathrm{~m} \text { speed } \\
\text { performances, leg strength and agility in } \\
\text { female futsal players. }\end{array}$ \\
\hline $\begin{array}{l}\text { RBFF-Revista } \\
\text { Brasileira de Futsal } \\
\text { e Futebol }\end{array}$ & $\begin{array}{l}\text { Prevalência e perfil } \\
\text { de lesões esportivas } \\
\text { em atletas de Futsal } \\
\text { feminino nos jogos } \\
\text { universitários brasileiros }\end{array}$ & $\begin{array}{l}\text { Martins de } \\
\text { Souza Filho et al. }\end{array}$ & 2018 & $\begin{array}{l}\text { The aim of this study was to } \\
\text { analyze the profile of athletic } \\
\text { injuries in female athletes of the } \\
\text { College Premier Futsal League } \\
\text { during the Brazilian college sports } \\
\text { competitions } 2014 \text {. }\end{array}$ & $\begin{array}{l}\text { Non-contact lesions with other athletes } \\
\text { presented higher prevalence than lesions } \\
\text { associated with contact. There was } \\
\text { prevalence of single-record injuries when } \\
\text { compared to injury re-occurrences. The } \\
\text { prevalence of injuries per match showed } \\
\text { high positive correlation with the day of } \\
\text { the competition, a statistically significant } \\
\text { result. }\end{array}$ \\
\hline Int J Sports Med & $\begin{array}{l}\text { Epidemiology of injuries } \\
\text { in elite female futsal } \\
\text { players: a prospective } \\
\text { cohort study }\end{array}$ & Lago et al. & 2020 & $\begin{array}{l}\text { The aim of this study was to analyze } \\
\text { the injury incidence, characteristics } \\
\text { and burden among a cohort of elite } \\
\text { female futsal players. }\end{array}$ & $\begin{array}{l}\text { The quadriceps and ankle were the regions } \\
\text { where most injuries occurred. Contact in- } \\
\text { juries were more common during matches } \\
\text { than training, and usually happened at the } \\
\text { end of the season. Elite female futsal players } \\
\text { are exposed to a substantial injury risk, } \\
\text { especially on ankle and quadriceps with } \\
\text { moderate severity, occurring at the end of } \\
\text { the sessions, especially during matches. }\end{array}$ \\
\hline
\end{tabular}




\begin{tabular}{|c|c|c|c|c|c|}
\hline Journal & Article title & Authors & Year & The purpose of the study & Results and conclusions \\
\hline Sustainability & $\begin{array}{l}\text { Healthy practice of } \\
\text { female soccer and } \\
\text { futsal: identifying } \\
\text { sources of stress, } \\
\text { anxiety and depression }\end{array}$ & Olmedilla et al. & 2018 & $\begin{array}{l}\text { The aim of this study was } \\
\text { to examine the post-injury } \\
\text { psychological impact looking to } \\
\text { avoid sources of health issues. }\end{array}$ & $\begin{array}{l}\text { The female non-injured players } \\
\text { presented values in anxiety higher than } \\
\text { those corresponding to the non-injured } \\
\text { male players. }\end{array}$ \\
\hline $\begin{array}{l}\text { Revista Brasileira } \\
\text { de Medicina Do } \\
\text { Esporte }\end{array}$ & $\begin{array}{l}\text { Propriocepção e } \\
\text { reforço muscular } \\
\text { na estabilidade do } \\
\text { tornozelo em atletas de } \\
\text { futsal feminino. }\end{array}$ & Oscar Ribas et al. & 2017 & $\begin{array}{l}\text { To compare the effects of } \\
\text { proprioceptive training and muscle } \\
\text { strengthening on the stability of the } \\
\text { ankle joint in indoor soccer athletes } \\
\text { through the Star Excursion Balance } \\
\text { Test. }\end{array}$ & $\begin{array}{l}\text { Both proprioceptive training and } \\
\text { muscle strengthening training obtained } \\
\text { statistically significant results and } \\
\text { demonstrated good stability of the ankle } \\
\text { joint. }\end{array}$ \\
\hline PeerJ. & $\begin{array}{l}\text { Injury incidence, } \\
\text { characteristics and } \\
\text { burden among female } \\
\text { sub-elite futsal players: } \\
\text { a prospective study with } \\
\text { three-year follow-up. }\end{array}$ & Ruiz-Pérez et al. & 2019 & $\begin{array}{l}\text { The main purpose of the current } \\
\text { study was to analyze the injury } \\
\text { incidence, characteristics and } \\
\text { burden among sub-elite female } \\
\text { futsal players. }\end{array}$ & $\begin{array}{l}\text { The injuries with the highest injury } \\
\text { burden were those that occurred at } \\
\text { the knee, followed by quadriceps and } \\
\text { hamstring strains. }\end{array}$ \\
\hline Asian J Sports Med & $\begin{array}{l}\text { Studying the Perceptive } \\
\text { and Cognitive Function } \\
\text { Under the Stress of } \\
\text { Match in Female Futsal } \\
\text { Players. }\end{array}$ & Sepahvand et al. & 2017 & $\begin{array}{l}\text { The main purpose of this study } \\
\text { was to analyze the effect of } \\
\text { match-related stress on cognitive } \\
\text { performance factors before and } \\
\text { after matches among female futsal } \\
\text { players. }\end{array}$ & $\begin{array}{l}\text { The results indicated that in female futsal } \\
\text { players, cortisol concentration in plasma } \\
\text { was much higher before the match, } \\
\text { compared with its concentration after } \\
\text { the match. }\end{array}$ \\
\hline \multicolumn{6}{|c|}{ Other topics investigated* } \\
\hline $\begin{array}{l}\text { RBNE-Revista } \\
\text { Brasileira De } \\
\text { Nutrição Esportiva }\end{array}$ & $\begin{array}{l}\text { Estado nutricional e } \\
\text { perfil alimentar de uma } \\
\text { equipe escolar de Futsal } \\
\text { feminino no município } \\
\text { de Caxias do Sul-RS }\end{array}$ & Batalha et al. & 2019 & $\begin{array}{l}\text { Evaluate the nutritional status and } \\
\text { food profile of a school team of } \\
\text { futsal players. }\end{array}$ & $\begin{array}{l}\text { The results showed that the team } \\
\text { is eutrophic and, according to the } \\
\text { waist circumference, is not at risk for } \\
\text { cardiovascular diseases. The percentage } \\
\text { of fat is adequate and the athletes } \\
\text { have good eating habits, although the } \\
\text { associations between the variables } \\
\text { studied were not statistically significant. }\end{array}$ \\
\hline $\begin{array}{l}\text { RBFF-Revista } \\
\text { Brasileira de Futsal } \\
\text { e Futebol }\end{array}$ & $\begin{array}{l}\text { A mulher em } \\
\text { quadra: evidências } \\
\text { contemporâneas do } \\
\text { contato inicial com } \\
\text { futsal }\end{array}$ & Costa et al. & 2018 & $\begin{array}{l}\text { This study aimed to highlight } \\
\text { the beginning of the relationship } \\
\text { between women and playing (futsal } \\
\text { mode). }\end{array}$ & $\begin{array}{l}\text { It was possible to conclude that female } \\
\text { sportive initiation usually takes place in } \\
\text { informal spaces and evolves into formal } \\
\text { education late, their experience in the } \\
\text { modality is stimulated by family and } \\
\text { friends and the participation of these } \\
\text { girls in competitions takes place at an } \\
\text { opportune moment. }\end{array}$ \\
\hline $\begin{array}{l}\text { RBNE-Revista } \\
\text { Brasileira De } \\
\text { Nutrição Esportiva }\end{array}$ & $\begin{array}{l}\text { Avaliação de hábitos } \\
\text { alimentares de uma } \\
\text { equipe de Futsal } \\
\text { feminino }\end{array}$ & Barbosa et al. & 2019 & $\begin{array}{l}\text { Evaluate the eating habits of a } \\
\text { female futsal team. }\end{array}$ & $\begin{array}{l}\text { Most athletes of the female futsal team, } \\
\text { make intake above or below the daily } \\
\text { recommendations for athletes, the data } \\
\text { in the tables show in detail the total daily } \\
\text { energy value as well as the amounts of } \\
\text { macronutrients consumed. }\end{array}$ \\
\hline $\begin{array}{l}\text { RBFF-Revista } \\
\text { Brasileira de Futsal } \\
\text { e Futebol }\end{array}$ & $\begin{array}{l}\text { Caracterização do } \\
\text { perfil dos treinadores } \\
\text { de futsal feminino de } \\
\text { equipes que disputam } \\
\text { os jogos abertos de } \\
\text { Pelotas }\end{array}$ & $\begin{array}{l}\text { de Freitas Vargas } \\
\text { et al. }\end{array}$ & 2017 & $\begin{array}{l}\text { The aim of this study was to charac- } \\
\text { terize the profile of women's futsal } \\
\text { coaches of teams that competed in } \\
\text { the Pelotas open games. }\end{array}$ & $\begin{array}{l}\text { The main difficulties cited for working } \\
\text { with women's futsal were lack of finan- } \\
\text { cial support, sponsorship, base category } \\
\text { teams, prejudice of families and a few } \\
\text { competitions. }\end{array}$ \\
\hline $\begin{array}{l}\text { Revista Brasileira } \\
\text { de Medicina do } \\
\text { Esporte }\end{array}$ & $\begin{array}{l}\text { Relative age in } \\
\text { female futsal athletes: } \\
\text { implications on } \\
\text { anthropometric profile } \\
\text { and starter status. }\end{array}$ & $\begin{array}{l}\text { Aires Ferreira } \\
\text { et al. }\end{array}$ & 2020 & $\begin{array}{l}\text { To determine the effect of relative } \\
\text { age (ERA) on competitive female } \\
\text { futsal athletes, and its influence on } \\
\text { anthropometric profile and starter } \\
\text { status. }\end{array}$ & $\begin{array}{l}\text { There was no ERA in distribution, } \\
\text { anthropometric profile, or starter status } \\
\text { between athletes born from January to } \\
\text { June and those born between July and } \\
\text { December. On the other hand, those } \\
\text { born in the first months of the year } \\
\text { showed longer practice times than those } \\
\text { born in the latter months of the year. }\end{array}$ \\
\hline
\end{tabular}




\begin{tabular}{l|l|l|l|l|l}
\hline Journal & Article title & Authors & Year & The purpose of the study & Results and conclusions \\
\hline $\begin{array}{l}\text { RBFF-Revista } \\
\text { Brasileira de Futsal } \\
\text { e Futebol }\end{array}$ & $\begin{array}{l}\text { Efeitos de um programa } \\
\text { periodizado de futsal } \\
\text { na aptidão física de } \\
\text { estudantes femininas } \\
\text { de 13 e 14 anos de } \\
\text { idade. }\end{array}$ & $\begin{array}{l}\text { Fiorante \& } \\
\text { Pellegrinoti }\end{array}$ & 2018 & $\begin{array}{l}\text { The objective of this study is to } \\
\text { analyze the effects on the physical } \\
\text { fitness of female students of full- } \\
\text { time school from a periodic futsal } \\
\text { program }\end{array}$ & $\begin{array}{l}\text { The intervention group showed a } \\
\text { significant difference in abdominal } \\
\text { resistance, square test and 6-minute } \\
\text { walk / walk tests in relation to the control } \\
\text { group }\end{array}$ \\
\hline Motriz & $\begin{array}{l}\text { Brazilian women } \\
\text { elite futsal players' } \\
\text { career development: } \\
\text { diversified experiences } \\
\text { and late sport } \\
\text { specialization }\end{array}$ & Mascarin et al. & 2019 & $\begin{array}{l}\text { To investigate elite women sports } \\
\text { career development can be a } \\
\text { way to better understand how } \\
\text { gender issues and specific women } \\
\text { sport practice conditions have } \\
\text { influenced athletes'life and personal } \\
\text { experiences, also subside reflections } \\
\text { on policies and pedagogic } \\
\text { intervention on the sport }\end{array}$ & $\begin{array}{l}\text { Interviewed players had their first sports } \\
\text { experiences on a variety of practices } \\
\text { during sport initiation in childhood }\end{array}$ \\
\hline
\end{tabular}

* Repeated studies in the different categories

As can be seen in Table 1, from 2015 to 2020 the category of Research related to conditioning factors of training and competition in women has gathered a total of 12 studies. The category of Investigations related to injuries and other psychological variables in women has had a total of 8 studies and, finally, the category of other topics studied has brought together a total of 8 studies.

\section{Discussion}

\section{Research related to conditioning factors of training and competition in women}

For Ruppel da Rocha and Delia Venera ${ }^{14}$, aerobic and muscular endurance, lower limb flexibility, muscular power, agility / speed and submaximal strength were developed during the preparatory period; in the competitive period, the technical and tactical components had greater emphasis and the physical capacities were maintained, with the total of injuries being $17 \%$. Thus, periodization with selective loads is adequate and meets the demands imposed by the modality, reducing the incidence of injuries during the competitive season of female Futsal athletes ${ }^{14}$. The analysis of futsal in women provides useful information on their external load demands ${ }^{15}$. These authors Beato et al. ${ }^{15}$ indicated that female futsal players decreased the workload in the second half compared to the first during a non-competitive match and found that fatigue impaired performance in the second half of the game. The results of another research Pascual Verdú et $a l .{ }^{16}$ showed that the modified match session obtains values for Heart Rate (HR) and subjective perception of effort greater than the technical-tactical and work sessions physical training of a female futsal team of the first national division. Likewise, for Clemente et al. ${ }^{17}$ the tactical tasks and the match were the activities that contributed to the largest increases in maximum HR. However, Barth et al. ${ }^{18}$ found no differences in maximum HR and only found differences in internal load between Small Sided Games and simulated matches. The results of these researchers ${ }^{19}$ show that the sessions with simulated match and Small Sided Game show similar psychological and physio- logical responses, but lower than those observed in training sessions with repeated sprinting. Likewise, according to Barbero-Alvarez et al. ${ }^{9}$, the peak HR and blood lactate concentrations after exercise were not significantly different between the tests in elite futsal players who have moderate aerobic fitness. Kassiano et al. ${ }^{19}$ showed that although blood lactate increased in female futsal players, their performance was not suppressed during and immediately after a friendly game, suggesting that the neuromuscular system can be restored immediately after the game end.

Karavelioglu et al. ${ }^{20}$ defined the effects of an 8-week plyometric training program on anaerobic capacity, leg strength, vertical jump, and speed values in women and observed a statistically significant difference in leg power, absolute peak power, absolute average power, vertical jump and speed. For their part, Teixeira et al. ${ }^{21}$ noted that in elite women's futsal, shuttle running interval training is a promising strategy to improve performance-related physical fitness attributes over a 5-week period during preseason, due to a better effect on aerobic and anaerobic qualities. Following Chernysheva et al. ${ }^{10}$ the simulation of situations of competitive activity in training conditions allows improving the capacities of futsal players to quickly perceive and adequately evaluate the current situation of the game, to make a decision based on the situation in terms of individual characteristics of the game functional status of the neuromuscular system and motor fitness. An improved central movement regulation mechanisms in girls contributes to effective physical performance when playing sports.

The central sectors of the field have the highest effectiveness rates. Therefore, the quadrants closest to the rival goal had the highest number of shots and goals scored, so it is necessary to modify the defensive systems of these regions to avoid possible negative results for the teams. Regarding the analytical performance system, the scout proved to be useful in analyzing various fundamentals of the sport, including the completions and the effective goals in a women's futsal championship ${ }^{22}$. In another study ${ }^{23}$ it was found that female players spent more time than male players in high-intensity areas and that futsal training sessions are more intense than soccer sessions. 


\section{Research related to injuries and other psychological variables in women}

Injuries are one of the worst scenarios for an athlete and a team ${ }^{24}$. Futsal is a team sport characterized by fast movements and high intensity, with frequent changes of direction of athletes, which predisposes the lower limb to injuries mainly in the ankle joint ${ }^{25}$. Following these lines, other authors ${ }^{26}$ pointed out that the characteristics of Futsal require players to perform frequent episodes of high intensity activity with limited rest periods that are not enough for a full recovery.

The main objective of another study ${ }^{27}$ was to analyse the incidence, characteristics and burden of injuries among women of the futsal sub-elite. Thus, the most common type of injury was muscle / tendon followed by joint (not bone) and ligament. The injuries with the highest injury load and that required the longest recovery time were those that occurred in the knee, followed by the quadriceps and hamstrings. On the other hand, in another study ${ }^{24}$ a total of 90 injuries were recorded, with $60.6 \%$ of the players suffering some type of injury. For these authors ${ }^{24}$, moderate or less severe injuries were the most frequent and they found that the majority of injuries occurred in the quadriceps and ankle. Following these contributions ${ }^{3}$ they observed a higher prevalence of injuries in the lower limbs, which are musculotendinous in the ankle and thigh. According to Oscar Ribas et al. ${ }^{25}$ both proprioceptive training and muscle strengthening training obtained statistically significant results in the ankle joint, improving stability. For other authors ${ }^{28}$ the injury rate in women who practice futsal was higher compared to men.

Most of the injuries had a non-contact mechanism (93\%), with the lower extremity being the most frequently injured anatomical region ${ }^{27}$. However, the results of another investigation ${ }^{3}$ indicated a prevalence of 2.16 injuries per game, with non-contact injuries being more frequent than injuries associated with contact with other players. Likewise, according to Lago et al. ${ }^{24}$ contact injuries were more common during matches than in training sessions and generally occurred more frequently at the end of the season in elite women's futsal competitions. On the other hand, for Ruiz-Pérez et al..$^{27}$ the first weeks of competition after preseason and shortly after the Christmas holidays were the times when the most injuries occurred. Therefore, futsal is presented as a risky sport with a high frequency of injuries, so it is necessary to carry out studies that address the factors related to this occurrence in order to guide future studies aimed at preventing new injuries and its recurrences ${ }^{3}$. To reduce the overall injury burden, efforts should be directed to the design, implementation, and evaluation of preventive measures that address the most common diagnoses, namely, muscle/ tendon and ligament injuries ${ }^{27}$.

On the other hand, another research ${ }^{29}$ examined the psychological impact after injury and for this they analysed the differences in levels of stress, anxiety and depression among players who they had suffered at least one injury during the season. The stress levels of uninjured players are higher than those of injured players. Compared with men, the uninjured female players presented higher anxiety values than those corresponding to the uninjured male players. Thus, sports injury affects mental health problems such as anxiety and stress, and differently in terms of gender ${ }^{29}$. Following this line, Sepahvand et al. ${ }^{30}$ indicated that stress negatively affects cognitive function in female futsal players, however, the effect of acute mental stress is not well understood. The results of these authors ${ }^{30}$ indicated that in women practicing futsal, the plasma cortisol concentration was much higher before the game, compared to its concentration after the game. It should also be noted that general health, sustained attention and response speed were higher after the match.

\section{Other topics investigated on women and futsal}

The results of Fiorante and Pellegrinoti ${ }^{31}$ showed that the dermatoglyphic profile of high-performance futsal athletes differs significantly from the profile of the non-athlete population. The results of Batalha et al. ${ }^{2}$ showed that the equipment is eutrophic and, based on waist circumference, it is not at risk of cardiovascular disease. The percentage of fat is adequate and the athletes have good eating habits and showed the importance of adequate and balanced nutrition guidelines to improve the physical performance and health of the players ${ }^{2}$. For Barbosa et al..$^{32}$ most of the players of an elite women's futsal team ingest above or below the daily recommendations for these athletes. Data obtained by other authors ${ }^{26}$ indicate that low-dose creatine supplementation for 7 days may be an effective approach to improve exercise capacity in women who practice futsal without an associated increase in body weight.

According to Aires Ferreira et al..$^{33}$, although the relative age revealed longer practice times that favour women born in the first quartile of the year, it did not influence the starter status, the distribution in the teams, or any advantage in the anthropometric profile. On the other hand, Costa et al. ${ }^{12}$ indicated that female sports initiation tends to occur in informal spaces and evolves towards late formal education, and their experience in the modality is stimulated by family and friends. Following these lines, Bevilaqua Mascarin et al.? indicated that the interviewed players had their first sporting experiences during childhood. Also, the beginning of systematic practice of specialization in futsal occurred later than in men due to the lack of competitions for women and the fact that futsal and other "kicking ball games" are considered more appropriate for men ${ }^{7}$. Likewise, the main difficulties cited by other authors' to work in women's futsal were the lack of financial support, sponsorships, grassroots teams, prejudices from families and the few existing competitions.

\section{Conclusions}

After the analysis of the 27 definitive articles for this systematic review of research on the presence of women in Futsal from 2015 to 2020 , it is concluded that: Research focused on women in futsal is more developed and in-depth than that of years ago, both in quantity and quality. As for the topics that have shown the greatest focus of interest among researchers, they have been studies on the conditioning factors of training, competition and injuries. On the contrary, the lack of studies related to the psychosocial field linked to the branch of sport psychology has become evident, with little research related to the emotional and mental performance or mental fatigue of the players. There has also been a shortage of studies that address the training and detection of talent in high performance in women futsal. 


\section{Practical applications and future research}

This research may be of interest to professionals in technical bodies, physicians, physiotherapists and psychologists. In a particular way, they are also relevant for all researchers who dedicate themselves to the study of futsal, since with this review they can learn first-hand about the topics most studied in recent years, and thus start new research projects or have clearer prospects and application needs of new research for the future.

The analysis of the different studies related to the presence of the figure of women in this sport helps to identify the diversity of lines of research related to the topic addressed and the degree of specificity thereof, giving the scientific community a global vision of the relevance and amount of research that has been published to date. For this reason, this review has the scientific evidence summarized in a global way, as well as a valuable compilation of the references available to the different professionals who study this field.

It is necessary to cover female futsal with a greater scientific contribution in all the topics investigated, given the great boom, extension and popularity that the figure of women has been acquiring within this sport in particular. With a view to future work carried out in futsal, it is advisable to provide studies related to the field of sports psychology, sociology and pedagogy, to learn more about the emotional, psychic and social relationship management demands that occur in futsal. They could contribute to the improvement of this sport and to greater sporting performance

\section{Conflict of interest}

The author do not declare a conflict of interest.

\section{Bibliography}

1. de Freitas Vargas L, Caputo EL, Silva MC. Caracterização do perfil dos treinadores de futsal feminino de equipes que disputam os jogos abertos de Pelotas. Rev Bras Fut. 2017;9:151-9.

2. Batalha TB, Gottardo FM, Conde SR, Alves MK. Estado nutricional e perfil alimentar de uma equipe escolar de Futsal feminino no município de Caxias do Sul-RS. Rev Bras Nut Sport. 2019;13:378-83

3. Martins de Souza Filho LF, Martins de Oliveira JC, Sperandio Barros G, Magnani RM, Silva Rebelo AC, Inumaru S. Prevalência e perfil de lesões esportivas em atletas de Futsal feminino nos jogos universitários brasileiros. Rev Bras Fut. 2018;10:729-35.

4. Lago C, Jiménez A, Padrón A, Mecías M, Rey E. Perceptions of the technical staff of professional teams regarding injury prevention in Spanish national futsal leagues: a cross-sectional study. PeerJ. 2020;8:e8817.

5. Sanmiguel-Rodríguez A, Arufe Giráldez V. Mujer, niños y variables psicosociales en el fútbol español. Una revisión bibliográfica de los años 2015-2019. Movimento. 2019; 25:25097.

6. Tamashiro LI, Galatti LR. Preconceito no Futsal e Futebol feminino nas revistas brasileiras: uma revisão bibliográfica. Rev Bras Fut. 2018;10:795-99.

7. Bevilaqua Mascarin R, Vicentini L, Rodrigues Marques RF. Brazilian women elite futsal players' career development: diversified experiences and late sport specialization. Motriz. 2019;25

8. Anas F. The Social Construction of Female Futsal Players in Surabaya. Indon J Gen Wom Child Soc Inc Stud. 2020;3:1-9.

9. Barbero-Alvarez JC, Subiela JV, Granda-Vera J, Castagna C, Gómez M, Del Coso J. Aerobic fitness and performance in elite female futsal players. Biol Sport. 2015;32:339.
10. Chernysheva EN, Primak IS, Smirnova SA, Pryanishnikova, OA. Innovative approach in modeling of motor training of women's futsal teams. Theor Pract Phys Cult. 2015;15.

11. da Silva Caldas E, Barros da Silva DM, Galvão de Miranda BL, Veras da Silva EA, Araújo Souza D, Furtado Marques R, Lemos de Araújo M. Análise dos fundamentos técnicos defensivos durante competições de Futsal Feminino. Rev Bras Fut. 2019;11:324-27.

12. Costa JE, Dias N, Oliveira EA, Aburachid LC, Grunennvaldt JT. A mulher em quadra: evidências contemporâneas do contato inicial com futsal. Rev Bras Fut. 2018;10:694-702.

13. Vieira Menezes R, Guilherme Lopes A. Influência de um período de preparação física na capacidade de resistência aeróbia em universitárias praticantes de futsal. Rev Bras Pres Fisiol Exer. 2015;9:617-21.

14. Ruppel da Rocha RE, Delia Venera G. Effecto de la periodización con cargas selectivas sobre la incidência de lesiones en un equipo de futsal femenino durante temporada competitiva. Rev Bras Fut. 2015;7:128-38.

15. Beato M, Coratella G, Schena F, Hulton AT. Evaluation of the external and internal workload in female futsal players. Biol Sport. 2017;34:227.

16. Pascual Verdú N, Llorca Estruch V, Carbonell Martínez JA, Pérez Turpin JA. Análisis de la carga interna en los entrenamientos de fútbol sala femenino de 1a división nacional. Revista Técnico-Científica del Deporte Escolar, Educación Física y Psicomotricidad. 2016;2:254-67

17. Clemente FM, Nikolaidis PT, Bezerra JP, Chen YS. Heart rate variations between training days and types of exercise in men and women futsal and soccer players. Hum Movt. 2018;19:1-7.

18. Barth J, Ribeiro YS, Picanco LM, Del Vecchio FB. Comparison of psychophysiological responses in game simulation and different training sessions in female futsal athletes. J Exerc Physiol Online. 2016;19:10-7.

19. Kassiano W, Jesus K, Assumpção C, Lamboglia C, Mendes A, Barbosa R, et al. Physiological and neuromuscular responses during the game in female futsal players. J Phys/ Edu. 2019;30:e3061.

20. Karavelioglu MB, Harmanci H, Kaya M, Erol M. Effects of plyometric training on anaerobic capacity and motor skills in female futsal players. Anthropologist. 2016;23:355-60.

21. Teixeira AS, Arins FB, De Lucas RD, Carminatti $\sqcup$, Dittrich N, Nakamura FY, Guglielmo LGA. Comparative effects of two interval shuttle-run training modes on physiological and performance adaptations in female professional futsal players.J Strength Cond Res. 2019;33:1416-28.

22. Galvão de Miranda BL, Barros da Silva DM, da Silva Caldas E, Rodrigues Pestana E, Lemos De Araújo M. Incidência local de finalizações e Gols efetivados em um campeonato de Futsal feminino. Rev Bras Fut. 2019;11:77-81.

23. Clemente FM, Nikolaidis PT. Profile of 1-month training load in male and female football and futsal players. SpringerPlus. 2016;5:694.

24. Lago C, Jiménez A, Padrón A, Mecías M, García F, Rey E. Epidemiology of injuries in elite female futsal players: a prospective cohort study. Int J Sports Med. 2020.

25. Oscar Ribas L, Boeira Schedler F, Pacheco I, Moré Pacheco A. Propriocepção e reforço muscular na estabilidade do tornozelo em atletas de futsal feminino. Rev Bras Med Esp. 2017;23:412-7

26. Atakan MM, Karavelioğlu MB, Harmancı H, Cook M, Bulut S. Short term creatine loading without weight gain improves sprint, agility and leg strength performance in female futsal players. Sci Sport. 2019;34:321-7.

27. Ruiz-Pérez I, López-Valenciano A, Jiménez-Loaisa A, Elvira JL, De Ste Croix M, Ayala F. Injury incidence, characteristics and burden among female sub-elite futsal players: a prospective study with three-year follow-up. Peer J. 2019;7: e7989

28. Ahmad-Shushami AH, Abdul-Karim S. Incidence of football and futsal injuries among youth in Malaysian Games 2018. Malays Orthop J. 2020;14:28.

29. Olmedilla A, Ortega E, Robles-Palazón FJ, Salom M, García-Mas A. Healthy practice of female soccer and futsal: identifying sources of stress, anxiety and depression. Sustainability. 2018;10:2268.

30. Sepahvand H, Pirzad Jahromi G, Sahraei H, Meftahi GH. Studying the Perceptive and Cognitive Function Under the Stress of Match in Female Futsal Players. Asian J Sports Med. 2017;8.

31. Fiorante FB, Pellegrinoti IL. Efeitos de um programa periodizado de futsal na aptidão física de estudantes femininas de 13 e 14 anos de idade. Rev Bras Fut. 2018;10:285-93.

32. Barbosa AK da S, Caldas E da S, da Silva DMB, Araújo ML, Navarro AC. Avaliação de hábitos alimentares de uma equipe de Futsal feminino. Rev Bras Nutr Esp. 2019;13:283-8.

33. Aires Ferreira S, Amarante do Nascimento M, Cavazzotto TG, Reis Weber VM, Peikriszwili Tartaruga M, Queiroga MR. Relative age in female futsal athletes: implications on anthropometric profile and starter status. Rev Bras Med Esp, 2020;26:34-8. 